\title{
Gambaran Tingkat Kecemasan dan Stres Kerja Tenaga Kesehatan Puskesmas Saat Pandemi Covid-19
}

\author{
Hendryk Priyatna ${ }^{1}$, Muhammad Mu'in ${ }^{1 *}$, Elsa Naviati ${ }^{1}$, Sari Sudarmiati ${ }^{1}$ \\ ${ }^{1}$ Departemen Ilmu Keperawatan, Fakultas Kedokteran, Universitas Diponegoro, Semarang, Indonesia \\ muhammadmuin@fk.undip.ac.id
}

\begin{abstract}
Introduction: The rapid growth of number of COVID-19 cases every day has made the condition of health workers increasingly depressed. These conditions can affect the level of anxiety and work stress. A study involving health workers caring for Covid-19 patient showed anxiety symptoms and work stress experience. The existence of anxiety and work stress can have an impact on increasing work errors, deteriorating physical and mental conditions, reducing productivity and decreasing service's quality. This study aims to describe the anxiety level and work stress of health workers during Covid-19 pandemic at the Public Health Center (Puskesmas).

Methods: This research was a descriptive survey study with 156 respondents from nine Puskesmas obtained through cluster and quota sampling calculation. Data was taken using Depression Anxiety Stress Scale (DASS-42) and workplace Stress Scale (WSS) questionnaires which distributed via google form.

Results: The results of this study obtained $16.7 \%$ of Puskesmas health workers experience anxiety consisting of $5.8 \%$ mild, $7.7 \%$ moderate, $2.6 \%$ severe and $0.6 \%$ very severe anxiety. Meanwhile, the work stress study obtained as many as $68.7 \%$ experience work stress, consisting of low 35.3\%, moderate $27.6 \%$, and heavy work stress $5.8 \%$.

Conclusion: Failure to manage anxiety and work stress can have a negative impact on mental health and can even endanger the lives of health workers. The findings in this study indicate risk for mental health disorders for health workers due to the Covid-19 pandemic. So it is necessary for relevant agencies and also individual itself, to manage anxiety and work stress.
\end{abstract}

Keywords : Anxiety, COVID-19, Health Worker, Work Stress.

\begin{abstract}
Abstrak
Pendahuluan: Peningkatan kasus COVID-19 mengakibatkan kondisi tenaga kesehatan mengalami tekanan. Kondisi tersebut dapat mempengaruhi tingkat kecemasan dan stres kerja tenaga kesehatan. Penelitian sebelumnya pada tenaga kesehatan yang melakukan perawatan pasien COVID-19 di rumah sakit menunjukkan gejala kecemasan serta stress kerja. Adanya kecemasan dan stres kerja dapat berdampak pada meningkatnya kesalahan kerja, memburuknya kondisi fisik dan mental, menurunnya produktifitas kerja, dan menurunnya kualitas pelayanan. Penelitian ini bertujuan untuk mendeskripsikan tingkat kecemasan dan stres kerja tenaga kesehatan saat pandemi COVID-19 di Puskesmas.
\end{abstract}

Hendryk Priyatna, dkk., Gambaran Tingkat Kecemasan dan Stres Kerja... 
Metode: Penelitian ini merupakan penelitian deskriptif dengan metode survei dengan sampel sejumlah 156 responden. Teknik pengambilan sampling adalah cluster dan quota sampling. Kuesioner yang digunakan adalah Depression Anxiety Stress Scale (DASS-42) untuk mengukur kecemasan dan workplace Stress Scale (WSS) untuk mengetahui stress kerja. Pengumpulan data dilakukan secara online malalui google form.

Hasil: Hasil penelitian menyatakan bahwa terdapat kecemasan sejumlah $16,7 \%$ yang meliputi cemas ringan $5.8 \%$, cemas sedang $7,7 \%$, cemas berat $2,6 \%$ dan cemas sangat berat $0,6 \%$. Terdapat stress kerja sebesar $68.7 \%$ yang terdiri dari stres kerja rendah $35,3 \%$, sedang $27,6 \%$, dan stres kerja berat $5,8 \%$.

Kesimpulan: Kegagalan dalam mengelola kecemasan dan stres kerja dapat berdampak negatif pada kesehatan mental dan bahkan dapat membahayakan nyawa tenaga kesehatan. Temuan dalam penelitian ini mengindikasikan bahwa tenaga kesehatan memiliki risiko terhadap gangguan kesehatan mental akibat situasi pandemi COVID-19. Sehingga perlu bagi instansi terkait maupun individu tenaga kesehatan untuk melakukan manajemen kecemasan dan stres yang dialami.

Kata Kunci : Cemas, COVID -19, Tenaga Kesehatan, Stres kerja.

\section{PENDAHULUAN}

Kecemasan dan stress kerja merupakan hal yang sering dikeluhkan oleh tenaga kesehatan di masa pandemi COVID-19. Sebuah studi yang dilakukan pada 34 rumah sakit di Tiongkok menunjukkan bahwa dari 1.257 petugas kesehatan yang melakukan perawatan pada pasien COVID-19 menunjukkan gejala depresi sebesar $50 \%$, insomnia 34\% dan tekanan psikologis $71.5 \%$ (Lai et al., 2020). Sedangkan Studi tentang stres kerja saat pandemi COVID-19 yang dilakukan terhadap 420 perawat di 2 rumah sakit Mesir mengemukakan hasil sebanyak masing-masing $75,2 \%$ dari 210 perawat di Zagazig fever hospital dan $60,5 \%$ dari 210 perawat di Zagazig general hospital mengalami stress kerja (Said \& El-Shafei, 2021).

Beberapa penelitian yang dilakukan pada tenaga kesehatan di Indonesia membuktikan bahwa tingginya tingkat kecemasan tenaga kesehatan dapat dipengaruhi oleh berbagai faktor seperti usia, status keluarga, kejujuran informasi yang diberikan pasien, kelengkapan alat pelindung diri, tingkat pengetahuan, jam kerja yang tinggi, stigma, dan kekhawatiran terpapar COVID-19 (Fadli dkk., 2020; Handayani dkk., 2020). Sedangkan Makarim (2014) menjelaskan adanya stres kerja ini disebabkan oleh berbagai faktor stressor kerja seperti kecemasan yang terjadi akibat adanya pengalaman kurang baik, ataupun peristiwa yang di alami di masa pandemi seperti adanya rekan sejawat yang terinfeksi atau meninggal akibat COVID-19, kemudian beban kerja yang berlebih karena peningkatan jumlah pasien, dan kondisi lingkungan kerja yang dirasakan dapat membahayakan kesehatan.

Park dan Kim (2013) menyebutkan dampak cemas dan stres kerja akan memperburuk kondisi fisik dan mental, meningkatkan kesalahan kerja, menurunkan produktivitas kerja tenaga kesehatan. Dampak terhadap instansi kesehatan dapat berupa menurunnya kualitas pelayanan yang disebabkan oleh berkurangnya rasa peduli terhadap pasien oleh tenaga kesehatan yang bisa berujung pada kesalahan dalam perawatan yang dapat membahayakan keselamatan pasien. 
Studi pendahuluan pada tenaga kesehatan tim satgas COVID-19 Puskesmas menunjukkan pada awalnya tidak mau menjadi anggota satgas karena cemas dan takut bila tertular dan menularkan keluarga di rumah, serta belum adanya APD yang sesuai standar bagi Puskesmas. Sebagian menyatakan bingung tentang penanganan COVID-19 di Puskesmas, hal ini menyebabkan keresahan dan memicu stress, terutama saat merujuk menggunakan ambulans Puskesmas.

Penelitian terhadap kecemasan dan stress kerja tenaga kesehatan di Puskesmas belum pernah dilakukan. Penelitian ini diharapkan dapat memberikan gambaran tingkat kecemasan dan stres kerja pada tenaga kesehatan saat pandemi COVID-19 di Puskesmas.

\section{METODE}

Penelitian ini adalah studi deskriptif dengan metode survei. Sampel penelitian ini adalah 156 responden yang didapatkan melalui teknik cluster dan quota sampling. Responden terdiri dari berbagai profesi tenaga kesehatan di 9 Puskesmas Kabupaten Belitung dengan kriteria inklusi tenaga kesehatan meliputi dokter, dokter gigi, perawat, perawat gigi, bidan, analis keshatan, nutrisionis, sanitarian, penyuluh kesehatan masyarakat, apoteker dan asisten apoteker; yang memberikan pelayanan kesehatan di dalam dan luar gedung Puskesmas, serta memiliki masa kerja minimal 1 tahun. Sedangkan kriteria eksklusinya adalah tenaga kesehatan yang bertugas di administrasi seperti pendaftaran, keuangan dan tata usaha serta sedang cuti saat proses pengambilan data.

Penelitian ini mendapat persetujuan dari Komite Etik Penelitian Kesehatan RSUD dr. Abdul Aziz Singkawang (No.
14/KEPK/2021). Kuesioner yang digunakan adalah Depression Anxiety Stress Scale 42 (DASS-42) dan The Workplace Stress Scale (WSS) Data dikumpulkan dengan google form yang dibagikan melalui Kepala Puskesmas yang selanjutnya disebarkan melalui grup whatsapp masing-masing Puskesmas kemudian data dianalisis dengan menggunakan statistik deskriptif di aplikasi SPSS versi 22. Informed consent penelitian juga disampaikan kepada calon responden melalui google form.

\section{HASIL}

Berikut adalah gambaran tingkat kecemasan dan stres kerja tenaga kesehatan saat pandemi COVID-19 di Puskesmas Kabupaten Belitung.

\begin{tabular}{lcc}
\hline $\begin{array}{l}\text { Tingkat } \\
\text { Kecemasan }\end{array}$ & Frekuensi & \% \\
\hline Cemas Normal & 130 & 83,3 \\
Cemas Ringan & 9 & 5,8 \\
Cemas Sedang & 12 & 7,7 \\
Cemas Berat & 4 & 2,6 \\
Cemas Sangat & 1 & 0,6 \\
Berat & & \\
Tingkat Stres & & \\
Kerja & & 31,4 \\
Stres Kerja & 49 & 35,3 \\
Ringan & & \\
Stres Kerja & 55 & 27,6 \\
Rendah & & \\
Stres Kerja & 43 & \\
Sedang & & 5,8 \\
Tingkat Stres & & 100 \\
Kerja & & \\
\hline Stres Kerja Berat & 9 & \\
\hline Total & 156 & \\
\hline
\end{tabular}

Berdasarkan Tabel 1 didapatkan tingkat kecemasan responden paling banyak berada pada tingkat cemas normal dan paling sedikit cemas sangat berat. Tingkat stres kerja responden paling tinggi 
berada pada tingkat stress kerja rendah dan paling sedikit stress kerja berat.

\section{PEMBAHASAN}

\section{Tingkat Kecemasan pada Tenaga Kesehatan saat Pandemi COVID-19 di Puskesmas}

Hasil penelitian yang dilakukan menunjukkan sebagian besar tenaga kesehatan mengalami tingkat cemas normal saat pandemi COVID-19. Hasil penelitin ini sejalan dengan beberapa penelitian yang telah dilakukan sebelumnya. Sebanyak 90\% tenaga kesehatan di China tidak mengalami kecemasan (Shen et al., 2020). Di Singapura dan India hanya sejumlah $15,7 \%$ responden saja yang mengalami kecemasan (Chen et al., 2020). Sedangkan di Indonesia menurut Vikawati (2021) tidak didapatkan kecemasan pada 151 orang dari 155 responden petugas kesehatan dalam menghadapi COVID-19.

Meskipun hasil tersebut cukup signifikan untuk dikatakan bahwa mayoritas responden tidak mengalami kecemasan ataupun cemas normal, namun $16,7 \%$ responden lainnya mengalami tingkat kecemasan yang cukup beragam, dari kecemasan ringan, sedang berat sampai sangat berat. Pada penelitian lain disebutkan bila $2,6 \%$ responden dalam penelitian tersebut hanya mengalami kecemasan ringan-sedang. Hasil temuan penelitian ini mengemukakan selain mendapatkan data kecemasan ringan dan sedang, juga didapatkan responden yang mengalami kecemasan berat dan sangat berat meskipun sejumlah $2,6 \%$ dan $0,6 \%$. Penggunaan metode dan alat penelitian yang berbeda mungkin menjadi penyebab adanya sedikit perbedaan (Vikawati, 2021).

Hasil penelitian ini juga didukung oleh penelitian Pinggian et al. (2021) yang mengemukakan bahwa situasi pandemi
COVID-19 menyebabkan peningkatan prevalensi kecemasan mulai dari ringan hingga berat. Data ini menggambarkan bahwa sebagian dari tenaga kesehatan yang mengalami tingkat kecemasan yang berbeda-beda walaupun pandemi COVID19 telah berlangsung selama lebih dari 1 tahun. Kecemasan yang pada awalnya dirasakan pada tingkat ringan dikhawatirkan dapat berkembang ke arah berat bahkan sangat berat dikarenakan tidak bisa mengendalikan rasa cemas akibat pikiran negatif terhadap situasi pandemi. Hal ini dikarenakan setiap tingkatan kecemasan mempunyai karakteristik atau manifestasi yang berbeda satu sama lain. Manifestasi kecemasan yang terjadi bergantung pada kematangan pribadi, pemahaman dalam menghadapi ketegangan, harga diri, dan mekanisme koping yang digunakannya (Asmadi, 2008).

Stuart (2007) menjelaskan bahwa kecemasan ringan pada umumnya menjadi bagian dari keseharian setiap individu yang merupakan respon peningkatan kewaspadaan dan perhatian terhadap suatu hal yang dapat dimanifestasikan menjadi sedikit kegelisahan, ketegangan otot ringan dan sedikit tidak sabaran. Namun bila kecemasan ringan tidak dikelola dengan baik akan menimbulkan peningkatan kecemasan sedang, yang menyebabkan timbulnya gejala yang kurang baik seperti mudah tersinggung, peningkatan tandatanda vital, mulai berkeringat, sering mondar-mandir dan sakit kepala. Berbagai tanda dan gejala tersebut bila dibiarkan akan membuat seseorang sulit untuk memikirkan hal lain selain apa yang dicemaskan, seseorang pun menjadi sulit untuk memecahkan permasalahannya yang pada akhirnya dapat menuju ke arah kecemasan berat. Individu yang mengalami kecemasan berat akan mulai merasakan takut, bingung, sangat cemas, kontak mata 
yang buruk, menarik diri, banyak berkeringat, bicara cepat dan gemetar. Hal tersebut jika dibiarkan terlalu lama akan menyebabkan kecemasan sangat berat atau panik dimana seseorang kehilangan kendali atas dirinya, dikuasai rasa takut dan merasakan teror, dan sulit untuk berpikir secara rasional. Tingginya tingkat kecemasan tenaga kesehatan dapat menurunkan motivasi kerja yang dapat membuat pelayanan yang diberikan menjadi kurang baik pada masyarakat (Ariasti \& Handayani, 2019). Bahkan menurut Winurini (2020) sebagian dari tenaga kesehatan yang mengalami kecemasan dan depresi memiliki pemikiran untuk mengakhiri hidupnya.

Cemas merupakan sebuah kondisi yang wajar dialami seseorang ketika menghadapi suatu permasalahan. perasaan cemas bila dikelola dengan baik dapat menimbulkan respon emosi yang positif seperti peningkatan kewaspadaan dan pemusatan perhatian dalam kondisi yang membutuhkan fokus. Namun bila gagal dalam mengelolanya dapat berdampak negatif terhadap kesehatan mental, bahkan tidak jarang beresiko kehilangan nyawa (Stuart, 2007). Handayani et al. (2020) menjelaskan berbagai metode pengelolaan kesehatan mental yang dapat diupayakan untuk menanggulangi kecemasan bagi tenaga kesehatan selama pandemi, antara lain melalui pembentukan kelompok pendukung upaya penyelesaian kecemasan atau battle buddies, penyediaan layanan konseling dan mengadakan pelatihan koping bagi tenaga kesehatan.

\section{Tingkat Stress Kerja Tenaga Kesehatan Saat Pandemi COVID-19 di Puskesmas}

Penelitian ini mengemukakan

bahwa 156 responden tenaga kesehatan yang bekerja saat pandemi COVID-19 sebagian besar mengalami stress kerja, yang terbagi menjadi beberapa tingkatan mulai dari rendah hingga berat dengan total $68,7 \%$ responden. Hasil ini cukup signifikan jika dibandingkan dengan temuan tingkat stres kerja ringan/normal yang berjumlah $31,4 \%$.

Penelitian Zulmiasari \& Mu'in (2017) sejalan dengan hasil temuan dalam penelitian ini, dimana sebagian besar perawat ditemukan mengalami stress kerja meskipun hanya berada pada tingkat stress kerja rendah. Hasil penelitian lainnya juga mendukung temuan penelitian ini, dimana ditemukan sejumlah $53,3 \%$ responden mengalami gejala stres tinggi (Nurazizah, 2017). Penelitian Kirana dan Dwianti (2017) memiliki temuan yang bertolak belakang dimana sebagian besar perawat ditemukan mengalami stress kerja namun masih dalam kategori yang normal. Perbedaan temuan ini dapat disebabkan oleh faktor kurang memadainya jumlah responden dan waktu penelitian yang dilaksanakan sebelum adanya wabah pandemi COVID-19.

Temuan stress kerja ini dapat disebabkan oleh berbagai faktor, seperti faktor situasi pandemi yang sedang dihadapi bisa menjadi pemicu stressor terhadap fenomena tersebut. Stressor tersebut dimanifestasikan dalam bentuk peningkatan kewaspadaan akan adanya paparan COVID-19 di lingkungan kerja tenaga kesehatan. Hal ini sesuai dengan pendapat Muthmainah (2012) yang menyebutkan bahwa salah satu penyebab stres kerja adalah terpaparnya tenaga kesehatan terhadap infeksi dan substansi berbahaya dari lingkungan kerja. Peningkatan risiko terpapar, terinfeksi dan menginfeksi keluarga menjadi penyebab stres bagi tenaga kesehatan (Kang et al., 2020).

Faktor penambahan beban kerja yang umumnya dialami akibat situasi pandemi oleh sebagian tenaga kesehatan diketahui merupakan sumber stressor yang 
juga dirasakan dampaknya. Hal ini didukung pendapat Doni (2021) yang menunjukkan bahwa semakin tinggi beban kerja, maka semakin tinggi stress kerja yang dialami tenaga kesehatan di masa pandemi. Tingginya tingkat stres kerja pada tenaga kesehatan juga ditemukan kaitannya dengan peningkatan beban kerja yang dihadapi saat pandemi COVID-19 (Said \& El-Shafei, 2021).

$$
\text { Hasil penelitian lain }
$$

menyimpulkan bahwa kurangnya ketersediaan alat pelindung diri (APD) dapat menjadi faktor pemicu timbulnya stressor bagi tenaga kesehatan, dimana ketika persediaan APD dirasakan kurang cukup akan menimbulkan perasaan cemas dan stres terkait penularan penyakit bagi tenaga kesehatan ketika sedang memberikan pelayanan kesehatan (Fadli et al., 2020). Fenomena ini didukung oleh penelitian Hasibuan (2021) yang menjelaskan bahwa salah cara untuk mencegah dan mengurangi tingkat stres tenaga kesehatan adalah dengan menjaga ketersediaan APD.

Faktor lainnya yaitu adanya peningkatan jam kerja yang dirasakan akibat adanya beberapa tenaga kesehatan yang harus diisolasi mandiri sehingga tugas yang ditinggalkan menjadi beban tambahan bagi tenaga kesehatan lainnya, sehingga sudah seharusnya tenaga kesehatan mendapatkan penghargaan yang sesuai (Setiyawati, 2021; Rimmer, 2020). Penghargaan yang dimaksud selain insentif dapat berbentuk apresiasi positif dari pimpinan berupa pemberian kesempatan mengikuti pelatihan atau workshop bersertifikat, cuti tambahan, satuan kredit profesi (SKP) dan bagi ASN dapat berupa kenaikan pangkat. Seseorang akan merasa tidak dihargai dan merasa diacuhkan oleh lingkungannya jika tidak mendapatkan dukungan sosial yang baik, hal itu akan memicu rasa pesimis atau tidak percaya diri, sehingga individu tersebut memiliki emosi yang negatif dan tidak mampu menjalin hubungan baik dengan lingkungannya (Setiyaningrum \& Dwityanto, 2014). Semakin rendah dukungan sosial, maka stress kerja pada tenaga kesehatan akan semakin tinggi (Kalembiro, 2012).

Stress kerja dialami berkepanjangan, tanpa henti dan semakin meningkat intensitasnya akibat situasi pandemi COVID-19 yang tidak terhindarkan ini dapat memicu komplikasi yang tidak diharapkan seperti kelelahan ekstrim, menurunnya kinerja, depresi atau bahkan burnout. Temuan dalam penelitian ini mengindikasikan bahwa tenaga kesehatan memiliki risiko terhadap gangguan kesehatan mental akibat situasi pandemi Covid-19. Sehingga perlu bagi instansi terkait untuk melakukan manajemen stress yang dialami tenaga kesehatan. Upaya yang dapat dilakukan dapat berupa strategi penanganan secara individual, organisasional dan dukungan sosial. Bentuk manajemen stress secara individu yaitu dengan beristirahat di sela jam kerja, rutin melakukan meditasi dan diet atau fitness. Sedangkan manajemen secara organisasi dijabarkan dalam bentuk penyederhanaan proses struktural dalam iklim organisasi, meningkatkan motivasi staf dengan cara memberikan penghargaan dan menempatkan orang yang tepat untuk posisi yang tepat agar menghindari ambiguitas peran. Terakhir, dukungan sosial oleh orang terdekat sebagai bentuk kepedulian terhadap tenaga kesehatan sebagai cara untuk membangun emosi positif dan meningkatkan kepercayaan diri (Gaffar \& Hulaifah, 2012).

\section{KESIMPULAN DAN SARAN}

Ditemukan tenaga kesehatan Puskesmas mengalami cemas sebesar 
$16,7 \%$ dan stres kerja sebesar $68,7 \%$. Temuan ini mengindikasikan bahwa tenaga kesehatan memiliki risiko terhadap gangguan kesehatan mental akibat situasi pandemi COVID-19.

Peneliti mendorong instansi terkait untuk mampu memanajemen cemas dan stres kerja tenaga kesehatannya, serta kepada seluruh tenaga kesehatan Puskesmas untuk mengendalikan perasaan cemas dengan saling menjaga kesehatan mental selama bertugas di masa pandemi. Hal yang dapat dilakukan yaitu saling mendukung antara rekan sejawat dengan saling meyakinkan agar tenaga kesehatan tidak pernah merasa sendirian dalam menghadapi situasi pandemi ini. Selanjutnya menjaga dan menciptakan hubungan yang baik dengan lingkungan kerja dengan menerapkan prinsip keselamatan kerja untuk meminimalisir risiko kerja. Hal ini akan dapat menurunkan stres kerja yang dihadapi.

\section{UCAPAN TERIMA KASIH}

Peneliti berterima kasih kepada Kementerian Kesehatan yang telah memberikan dana dalam pelaksanaan penelitian ini.

\section{DAFTAR PUSTAKA}

Ariasti, D., \& Handayani, A.,T. (2019). Hubungan tingkat kecemasan dengan motivasi kerja perawat di RSUD dr. Soeratno Gemolong. Kosala JIK,7(1),19-28.

Asmadi, A. (2008). Teknik prosedural keperawatan konsep dan aplikasi kebutuhan dasar klien. Jakarta: Salemba Medika.

Chen, W. S., Lee, G. K. H., Tan, B. Y. Q., Jung, M., Goh, Y., \& Ngiam, N., J.
H. (2020). A multinational, multicenter study on the psychological outcomes and associated physical symptoms amongst healthcare workers during COVID- 19 outbreak. Brain Behav Immun, 88, 559-65. doi: 10.1016/j.bbi.2020.04.049

Doni, E. 2021. Hubungan beban kerja dengan stres kerja perawat pelaksana saat pandemic COVID19 di Instalasi Bedah Sentral RSUP dr. M. Djamil Padang. Thesis, Fakultas Keperawatan Universitas Andalas.

Fadli, F., Safruddin, S., Ahmad, A.,S., Sumbara, S., \& Baharuddin, R. (2020). Faktor yang mempengaruhi kecemasan pada tenaga kesehatan dalam upaya pencegahan COVID19. J Pendidik Keperawatan Indones, 6(1), 57-65.

Gaffar, H. 2012. Pengaruh stres kerja terhadap kinerja karyawan pada PT. Bank Mandiri (PERSERO TBK Kantor Wilayah $X$ Makassar. Skripsi, Universitas Hasanudin.

Handayani R. T., Suminanto, Darmayanti, A. T., Widiyanto, A., \& Atmojo, J. T. (2020). Kondisi dan strategi penanganan kecemasan pada tenaga kesehatan saatpandemic covid-19. $J$ Ilmu Keperawatan Jiwa, 3(3), 36574.

Hasibuan, A. N. (2021). Faktor yang berhubungan dengan stres petugas kesehatan dalam penanganan COVID-19. doi:10.31219/osf.io/mkefq

Kalembiro, K. W. (2012). Dukungan sosial 
rekan kerja dan stres kerja peraear RSUD Kolondale, Sulawesi Tengah. Skripsi. Salatiga: Fakultas Psikologi Universitas Kristen Satya Wacana.

Kang, L. (2020). The mental health of medical workers in Wuhan, China dealing with the 2019 novel corona virus. The Lancet Psychiatry, 7, e14.

Kirana, V. D. S., \& Dwianti, E. (2017). Hubungan stres kerja dengan kelelahan pada perawat dengan metode pengukuran DASS-21 dan FIRC. Jurnal Ilmiah Kesehatan Media Husada, 6(1),133-40.

Lai, J., Ma, S., \& Wang, Y. (2020). Factors Associated with mental health outcomes among health care workers exposed to Coronavirus Disease 2019. JAMA Netw Open, 3(3).

Makarim, A. M. 2014. Hubungan antara stres kerja dengan pemilihan strategi koping pada perawat di Rumah Sakit Islam Unisma Malang. Skripsi, Universitas Islam Negeri Maulana Malik Ibrahim.

Muthmainah I. 2012. Faktor-faktor penyebab stres kerja di Ruangan ICU Pelayanan Jantung Terpadu dr. Cipto Mangun Kusumo. Thesis, UniversitasIndonesia.

Nurazizah. 2017. Faktor-faktor yang berhubungan dengan stres kerja pada perawat di ruang rawat inap kelas III rumah sakit X Jakarta. Skripsi, UIN Syarif Hidayatullah Jakarta.

Park, Y. M., \& Kim, S. Y. (2013). Impact of job stress and cognitive failure on patient safety inccidents among hospital nurse. Saf Health Work, 4, 210-215.

Pinggian, B., Opod, H., David, L. (2021). Dampak psikologis tenaga kesehatan selama pandemi Covid19. Jurnal Biomedik, 13(2),141151. doi: jbm.13.2.2021.31806

Rimmer A. (2020). Covid-19: Reward healthcare staff for pandemic work, says BMA. BMJ, 370, m3620. doi: 10.1136/bmj.m3602

Said, R., M., \& El-Shafei, D. A. (2021). Occupational stress, job satisfaction, and intent to leave: nurses working on front lines during COVID-19 pandemic in Zagazig City, Egypt. Env Sci Pollut Res, (28), 8791-8801. doi: $10.1007 / \mathrm{s} 11356-020-11235-8$

Setiyawati, Y. (2021). Covid-19 meningkat, beban nakes tinggi. Radar Bogor. Diakses Juni 03 2021 dari https://radarbogor.id/2021/01/18/co vid-19-meningkat-beban-nakes$\underline{\text { tinggi/ }}$

Setiyaningrum, P., \& Dwityanto, A. (2014). Hubungan antara stres kerja dengan dukungan sosial pada tenaga kesehatan non keperawatan di RS Orthopedi Prof. Dr. R. Soeharso. Tesis. Surakarta: Fakultas Psikologi Universitas Muhammadiyah.

Shen, M., Xu, H., Fu, J., Wang, T., Fu, Z., Zhao, X. ... Tong, G. (2020). Investigation of anxiety level of 1637 healthcare workers during the 
Covid-19 pandemic. PLOS ONE, 1-

8. doi:

$\underline{10.1371 / \text { journal.pone. } 0243890}$

Smet. (Ed). (1994). Psikologi kesehatan. Jakarta: PT. Gramedia Widia Sarana Indonesia.

Stuart, G.,W. (Ed). (2007). Buku saku keperawatan jiwa. Jakarta: EGC.

Vikawati, N. E., Nurrahma, H. A., Hardini, I. T., \& Hidajati, E. N. (2021). Tidak didapatkan kecemasan pada petugas kesehatan dalam menghadapi pandemi Covid-19. Syifa MEDIKA,11(2), 116-25.

Winurini, S. (2020). Permasalahan kesehatan mental akibat pandemi Covid-19. Info Singkat,12(15),1318.

Zulmiasari, \& Muin, M. (2017). Gambaran tingkat stres kerja pada perawat di pusat kesehatan masyarakat (Puskesmas) Kota Semarang. J Jur KEPERAWATAN, 1-8. 